\title{
Spectroscopic and elementary characterization of humic substances in organic substrates
}

Rubens Ribeiro da Silva', Guilherme Nunes Lucena²*, Ângela Franciely Machado', Gilson Araújo de Freitas', Antonio Teixeira Matos ${ }^{3}$, Walter Antônio Pereira Abrahão ${ }^{3}$

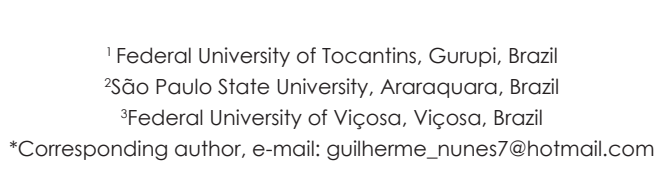

\begin{abstract}
The humic substances, major constituents of the organic matter of the substrates, play an important role in plant development, including: the availability of nutrients, the generation of negative charges (CEC) and the buffering effect. Based on this, this study aimed to use the molecular absorption spectroscopy in the ultraviolet-visible region (UV-VIS), the vibrational spectroscopy Fourier transform infrared (FTIR) and the elementary analysis $\mathrm{CHN} / \mathrm{O}$ techniques to characterize the humic acid (HA) and fulvic acid (FA) fractions of the humic substances of five organic substrates, named as T1, T2, T3, T4, and T5, which were produced at the Federal University of Tocantins - Campus Gurupi. The molecular absorption spectra in UV-VIS and FTIR on the T1, T2, T3, T4 and T5 substrates showed humification, the formation of negative charges, which is related to the cation exchange capacity (CEC) and the complexation of metal ions that are considered nutrients. The biggest humification was shown for the T4 substrate, in function of its higher cabon-acid humic/carbon-acid fulvic ratio and the lower $\mathrm{C} / \mathrm{N}$ ratio, allied to a negative charge generation, the low $E_{4} / E_{6}$ ratio found in the humic acid fraction. The complexation of metal nutrient ions indicates the greatest potencial of its use for seedlings production and the conservation of the chemical and physical properties of the organic substrate.
\end{abstract}

Keywords: fulvic acids, humic acid, organic waste

\section{Introduction}

The organic substrates used in the production of seedlings are formed by organic materials which contribute to the retention of humidity, nutrient supply, root growth, cation exchange capacity, $\mathrm{pH}$ regulation and physical support to ensure the development of the plant with quality (David et al., 2014; Pessoa et al., 2012).

Humic substances (HS), the main constituent of organic matter, present heterogeneous mixture of organic compounds aggregated by weak intermolecular interactions of hydrophobic nature and by hydrogen bonds (Matilainen et al., 2011; Valencia et al., 2013), which are fractionated in humic acids (HA), fulvic acids (FA) and humins (Baldotto et al., 2013); HS have a structural complexity due to the presence of organic functional groups that provide several functions in the nutrition of plants and improvement of the physical and chemical properties of the soil. This heterogeneous composition, derived from physicochemical and biological processes, makes it difficult to characterize SH. However, the composition of $\mathrm{SH}$ is always sought in the elaboration of organic substrates used in the production of seedlings.

Many analytical techniques have been used to identify important features of this structural complexity, for example, ultraviolet-visible (UV- 
VIS), Fourier transform infrared (FTIR) spectroscopy and elementary analysis (Rodríguez et al., 2014). UV-VIS spectroscopy is useful in determining the absorbance (ABS) of aromatic systems and the ratio $E_{4} / E_{6}$ (ABS at $465 \mathrm{~nm} / A B S$ at $665 \mathrm{~nm}$ ), which are related to the degree of humification of HS and, consequently, to the quality of the soil or the organic substrate (Rodríguez \& Núñez, 2011).

Infrared spectroscopy has also been widely used in the characterization of humic substances. This technique allows the identification of functional groups that compose the humic macromolecule, although a specific band may sometimes correspond to the overlap of the absorption of two distinct functional groups (Wang et al., 2014).

Furthermore, the elementary analysis provides data on percentages of carbon, hydrogen, nitrogen, and oxygen elements. The $\mathrm{H} / \mathrm{C}$ ratio is considered as the aromaticity index and the $\mathrm{O} / \mathrm{C}$ ratio estimates the abundance of oxygen contained in functional groups. The $\mathrm{C} / \mathrm{N}$ ratio indicates the degree of incorporation of nitrogen in HS, the degree of humification and the recalcitrant behavior (Silva et al., 2013).

Information regarding the complex chemical structure of HS present in organic substrates is scarce in the literature. This information can predict how these compounds act on the improvements in the chemical, physical and biological properties of the substrate in which the plants develop and, therefore, increase their productivity. Thus, the aim of the present study was to characterize the purified humic and fulvic acids of five organic substrates using the UV-VIS spectroscopy, the FTIR and the CHN/O elementary analysis techniques.

\section{Materials and Methods}

The study was conducted at the Federal University of Tocantins - Campus of Gurupi, at the geographical coordinates $11^{\circ} 43^{\prime} \mathrm{S}$ and $49^{\circ} 04^{\prime} \mathrm{W}$, where the five organic substrates were obtained from the composting process of bovine rumen residues enriched with different doses of meat and bone meal. The substrates were designated as $\mathrm{T} 1, \mathrm{~T} 2, \mathrm{~T} 3, \mathrm{~T} 4$, and $\mathrm{T} 5$, characterized in terms of the contents of N, P, K, Ca, Mg, S, Al, Na, Mo, and $\mathrm{Co}$ (Table 1). The substrate characterization analyzes performed according to the Embrapa methodology (2011) were carried out in the soil department of the Federal University of Viçosa in Viçosa, Minas Gerais state, at the geographic coordinates $20^{\circ} 45$ 'S and $42^{\circ} 55^{\prime}$ ' W.

Table 1. Chemical characterization of the five organic substrates

\begin{tabular}{|c|c|c|c|c|c|c|c|c|c|}
\hline Substrate & $\mathrm{N}$ & P & K & $\mathrm{Ca}$ & $\mathrm{Mg}$ & $S$ & $\mathrm{Na}$ & Mo & Co \\
\hline & \multicolumn{7}{|c|}{$\mathrm{g} \mathrm{kg}$} & \multicolumn{2}{|c|}{$\%$} \\
\hline $\mathrm{Tl}$ & 20.18 & 10.19 & 1.40 & 20.20 & 10.28 & 3.70 & 1.80 & 0.0016 & 0.0006 \\
\hline T2 & 20.30 & 20.04 & 1.60 & 20.86 & 10.34 & 3.60 & 2.00 & 0.0016 & 0.0003 \\
\hline T3 & 20.25 & 30.98 & 1.80 & 30.82 & 10.53 & 4.40 & 2.60 & 0.0015 & 0.0 \\
\hline T4 & 20.38 & 50.43 & 1.80 & 40.90 & 10.67 & 4.40 & 3.30 & 0.0015 & 0.0005 \\
\hline T5 & 10.92 & 1.40 & 1.30 & 7.60 & 8.40 & 3.20 & 0.7 & 0.0015 & 0.0004 \\
\hline
\end{tabular}

The experiment was carried out in two parts using the five substrates. In the first part, the humic and fulvic acid fractions were extracted, purified, lyophilized, and submitted to the spectroscopic and elemental analyzes. In the second part, a completely randomized design with four replications was followed. Each replicate was obtained by successive quartering, yielding four replicates of the substrates with unpurified total mass, each replicate being then subjected only to the CHN/O elementary analysis.

Humic acids (HA) and fulvic acids (FA) were extracted, purified and lyophilized according to IHSS (Swift, 1996). The extraction was carried out using alkaline solution ( $\mathrm{NaOH} 0.1$ $\mathrm{mol} \mathrm{L}^{-1}$, at the rate of $10 \mathrm{~mL}$ per gram of substrate) for solubilization of the humic and fulvic acid fractions and separation by centrifugation. After separation by centrifugation, the humic extract was acidified to $\mathrm{pH} 2.0$ for the separation of the two fractions by centrifugation. The FAs were purified using two columns with XAD-8 resins and Amberlite IR 120+ for the removal of impurities and salts, and then frozen and lyophilized, obtaining the dry material for analysis. The HAs were purified by means of 15 attacks with $10 \%$ $\mathrm{HF}$ solution $+0.5 \% \mathrm{HCl}$ for the removal of the HAbound to the mineral fraction, after which they 
were dialysed in deionized water for the removal of salts, frozen and lyophilized, obtaining the dry material for analysis. The dried material was then subjected to UV-VIS spectroscopy analysis and infrared spectroscopy and elemental analysis.

The measurements in the UV-VIS range were made using a GBC brand UV / VIS 911A scanning spectrophotometer, using quartz cells with a $1-\mathrm{cm}$ optical path. The readings in the visible range, both the scanning (230 to $700 \mathrm{~nm}$ ) and the determination of the absorbances at 465 and $665 \mathrm{~nm}$ were made in solutions of purified fulvic and humic acids, diluted appropriately in 0.05 mol L-1 sodium bicarbonate. The measurements in the ultraviolet range were made in solutions of purified fulvic acids, diluted in $\mathrm{pH}$-adjusted solutions to 2.0 with $\mathrm{HCl}$ and 12.0 with $\mathrm{NaOH}$, in addition to the neutral buffered bicarbonate solution. Differential spectra were calculated by the difference between the spectra obtained at $\mathrm{pH} 12.0$ and 2.0, expressing the absorbance data (Coelho et al., 2013).

The Fourier transform infrared spectra of humic and fulvic acids were read in the range of $4000-400 \mathrm{~cm}^{-1}$ in $\mathrm{KBr}$ pellets, using a Fourier transform infrared spectrometer FTIR Spectrum 1000. Each spectrum was obtained by the average of 128 measurements with resolution of $4 \mathrm{~cm}^{-1}$.

Elementary analysis was determined via combustion at $925^{\circ} \mathrm{C}$ using an Perkin Elmer
CHN Analyzer 2400 Series II elemental analyzer, directly quantifying the $\mathrm{C}, \mathrm{H}$ and $\mathrm{N}$ elements and obtaining the $\mathrm{O}$ content by difference $1 \% \mathrm{O}$ $=100 \%-\% \mathrm{C}-\% \mathrm{H}-\% \mathrm{~N})$. With the percentages of the elements $\mathrm{C}, \mathrm{H}, \mathrm{N}$, and $\mathrm{O}$, the elementary ratios $\mathrm{C} / \mathrm{N}, \mathrm{H} / \mathrm{C}$ e O/C for all HAs and $\mathrm{AFs}$, as well as the ratio between the $C$ contents of the $A H$ and the AF (CHA/CFA) were calculated.

The data were submitted to analysis of variance, and the means were compared by the Tukey test at 1 and $5 \%$ probability, using the Assistat 7.7 software (Silva \& Azevedo, 2016).

\section{Results and e discussion}

The visible ultraviolet (UV-VIS) absorption spectra of the humic acids (HA) and fulvic acids (FA) of the five organic substrates showed decreases in absorbance (ABS) with increasing wavelengths (Figure 1a and 1b). The HA (Figure 1a) showed a small peak of $A B S$ in at $270 \mathrm{~nm}$, which was evident in the five substrates. This absorbance occurs due to $\pi \rightarrow \pi$ * electronic transitions in aromatic systems such as phenolic groups, aniline derivatives of benzoic acids, polyenes and polycyclic aromatic hydrocarbons (Rodríguez et al., 2016). The FA (Figure 1b) did not show a peak at $270 \mathrm{~nm}$, suggesting a decrease in the amount of aromatic structures and, thus, their stability in relation to HA, corroborating with the structure suggested for the FA (Stevenson, 1994). All HAs and AFs in the $\mathrm{Tl}$ and $\mathrm{T} 2$

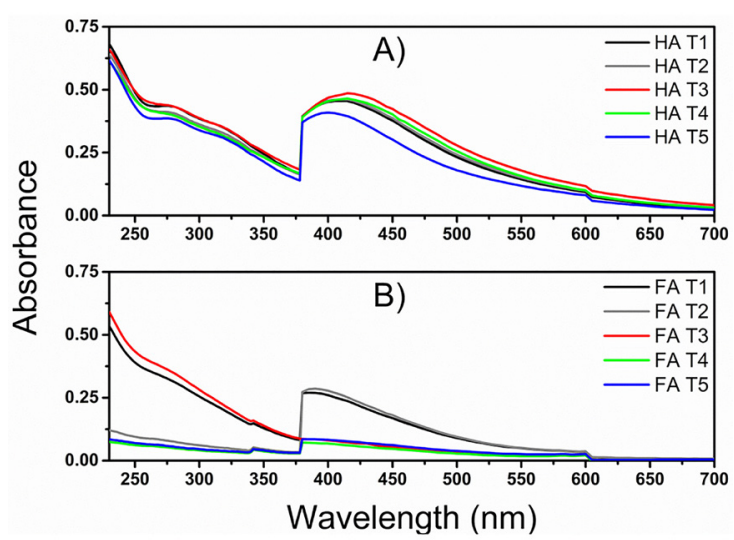

Figure 1. Ultraviolet-visible molecular absorption spectra of humic acids (1A) and fulvic acids (1B) purified from the five organic substrates.

treatments showed ABS band at $390 \mathrm{~nm}$. This is a characteristic behavior of HS substances and occurs due to the overlapping of peaks relative to different chromophoric groups, such as aromatic structures located in several points of the macromolecule and in several forms of conjugation of double bonds with simple bonds, occurring the splinting of the peaks and the 
junction of the same in a misshapen spectrum (McCarthy \& Rice, 1985).

The E4/E6 ratios of HA were lower than those of $A F$ (Figure 2). High $E_{4} / E_{6}$ is characteristic of $F A$, since it predicts the existence of less condensed aliphatic structures and a decrease in the conjugations of double and single bonds (Primo et al., 2011). Low $E_{4} / E_{6}$ is related to the increase in molecular weight, condensation of aromatic carbons, increased humification of aromatic structures, and greater conjugation of double and simple bonds characteristics of HA, which caused the studied HA to have greater stability and permanence in the substrate (Zalba et al., 2016; Dobbss et al., 2009).

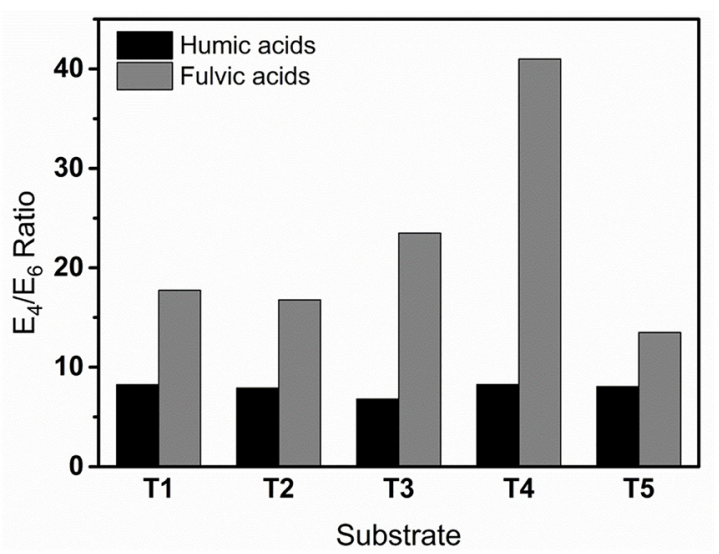

Figure 2. $E_{4} / E_{6}$ ratio of humic acids and fulvic acids purified from the five organic substrates.

The increased humification of the organic matter in the substrates is of great importance since several physiological processes of the plants can be modulated by the humic material, such as the large systems of energy transduction of the plant cell membranes and proton pumps, nutrient absorption, cell permeability and stimulation of $\mathrm{H}^{+}$-ATPase activity (Trevisan et al., 2010; Canellas et al., 2008)

Together with these physiological effects on plants, HS still play a key role in the root environment in which plants develop. Several positive effects on plant nutrition have been attributed to humic substances, including improvement in seed germination, root growth and initiation, and increases in total biomass (Graber et al., 2015).

In relation to the Fourier transform infrared (FTIR) absorption spectra of the HA and FA in the five organic substrates, it is possible to observe the higher structural complexity and relatively higher molecular mass of the HA in relation to the FA. This difference is evidenced by the greater presence of several absorption bands evident in the five substrates (Figures 3 and 4). In the case of humic substances, infrared absorption bands generally cannot be interpreted safely, so the recommendation for humic material is to use the comparative mode, comparing a spectrum against another (Primo et al., 2011). Therefore, the possible attributions of the absorption bands were made based on the studies of Rodríguez et al. (2016), Fernandes et al. (2010) and Stevenson (1994).

There was no major difference in the HA FTIR spectra of the five studied organic substrates (Figure 3). In the region around 3600 to $3000 \mathrm{~cm}$ - 1 the HA presented a strong and wide absorption band attributed to the symmetrical and/or asymmetric angular stretch of the $\mathrm{O}-\mathrm{H}$ bond of hydroxyl groups capable of forming hydrogen bonds, mainly carboxylic acids, alcohols and phenols. The presence of oxygenated functional groups favors the interaction of humic substances with organic and inorganic compounds, such as metallic ions (Thorn \& Cox, 2009). This interaction evidences the possibility of the HAs to maintain metallic ions present in the substrates, favoring their availability to the plants. Phenolic groups formed during the process of decomposition of organic matter are converted into quinones through oxidation reactions, which are precursors of semiquinone-like free radicals in $\mathrm{HA}$ that stabilize with the advancement of humification. 


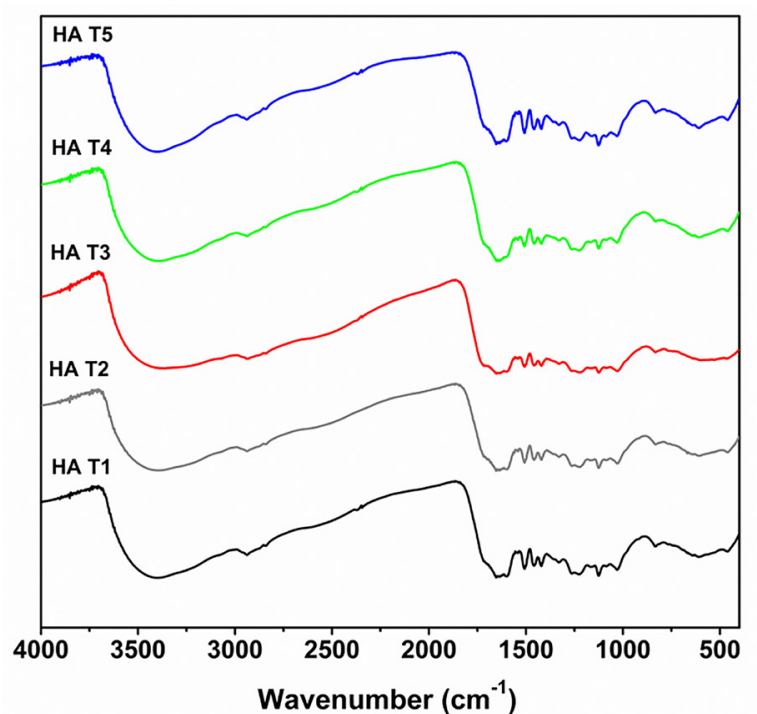

Figure 3. Infrared Spectra with Fourier Transform of purified humic acids from the five organic substrates.

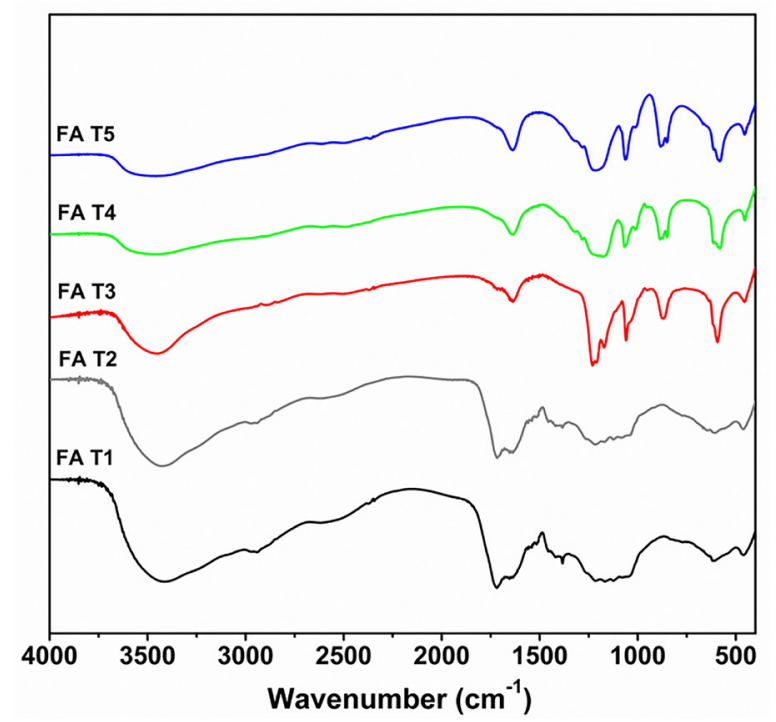

Figure 4. Fourier transform infrared spectra of fulvic acids purified from five organic substrates.

The increased concentration of semiquinone free radicals in HA can estimate the degree of humification of HS (Baldotto et al., 2011).

In the region attributed to the symmetrical stretching of $\mathrm{C}-\mathrm{H}$ bonds, mainly of methyl ($\mathrm{CH}_{3}$ ) groups, the FTIR spectra of the five organic substrates showed a sharp and well-defined absorption band centered at $2940 \mathrm{~cm}^{-1}$. Another acute, well-defined absorption band centered at $2840 \mathrm{~cm}^{-1}$ is also evident and is attributed to the symmetrical stretching of $-\mathrm{CH}_{2}$ groups. The existence of a narrow, intense and well-defined absorption band ranging from 1650 to $1590 \mathrm{~cm}^{-1}$, evident in the HA of the five substrates, indicates the presence of a series of symmetrical stretches of $\mathrm{C}=\mathrm{O}$ bonds of $\mathrm{COO}$, secondary amides and quinones. The presence of quinones becomes important since the redox properties of humic substances have been attributed to it, although complexed metals, particularly iron, may also perform redox activities. Thus, humic substances play important roles in the mechanisms of electron transfer during the microbial activity. They act as redox buffers, accepting electrons from microbial respiration under anoxic conditions and, after re-reaction, transfering electrons to oxygen (Aeschbacher et al., 2010).

The three well-defined and centered fine absorption bands at $1510 \mathrm{~cm}^{-1}$ found for all substrates are characteristic of the stretching 
of $\mathrm{C}-\mathrm{C}$ bonds of aromatic rings, indicating the presence of lignins and $\mathrm{N}=\mathrm{C}$ conjugated systems (Dobbss et al., 2009). Lignin is a compound of difficult decomposition, but it contributes to the formation of humic substances from its degradation and oxidation derivatives (Zhou et al., 2014; Fialho et al., 2010).

In the region between 1460 and 1420 $\mathrm{cm}^{-1}$, it is evident the presence of two absorption peaks attributed to deformations of $\mathrm{C}-\mathrm{H}$ bonds of methyl and methylene groups, and also possibly to an angular deformation of medium intensity of $-\mathrm{CH} 2$ groups in the $\mathrm{HA}$ of the five substrates. The presence of an intense and well-defined band ranging between 1270 and $1225 \mathrm{~cm}^{-1}$, with an absorption center at $1250 \mathrm{~cm}^{-1}$, is attributed to the presence of angular deformations of $\mathrm{O}-\mathrm{H}$ bonds in carboxylic groups and $\mathrm{C}-\mathrm{O}$ bonds in esters and the presence of phenols. The presence of carboxylic groups is important since the cation exchange capacity (CEC) has been related to the dissociation of functional groups that are $\mathrm{pH}$ dependent, mainly carboxylic acids (Smith et al., 2015).

The absorption band near $1100 \mathrm{~cm}^{-1}$ can be attributed to the presence of carboxylic groups bound to metal cations, both nutrients and pollutants. This suggests the existence of persistent inorganic material even after the HA purification (Miranda et al., 2007). This shows the ability Ahs to maintain the fertility of the substrates by supplying the plants with the necessary minerals to the development, growth, and quality index of the seedlings.

The presence of polysaccharides and alcohols can be attributed to the band centered at $1030 \mathrm{~cm}^{-1}$ due to stretches of $\mathrm{C}-\mathrm{O}$ bond, which is evident in the five organic substrates. However, this band can also be attributed to the presence of aluminosilicates that were not completely removed during the humic acid extraction process (Pernet-Coudrier et al., 2011).

Unlike the FTIR absorption spectra of the HA, the spectra of the FAs (Figure 4) did not present numerous absorption bands, which indicates less complexity of their chemical structure. In addition, there was a difference between the absorption spectra of the substrates, especially those related to the absorption of hydroxyl groups in hydrogen bonds, and a decrease in the absorption of these bands in FA3, FA4 and FA5, when compared to FAl and FA2. The fulvic acids FAl and FA2 showed similar FTIR absorption spectra, with a broad and well-defined absorption band ranging from 3600 to $3000 \mathrm{~cm}^{-1}$ that is characteristic of stretches of $\mathrm{O}-\mathrm{H}$ bonds. On the other hand, FA3, FA4 and FA5 also presented the hydroxyl-related band, however, with lower intensity, being an indication of the decrease in the amount of hydroxyl groups. The presence of methyl groups is evidenced by the absorption band at $2940 \mathrm{~cm}^{-}$ 1, which is attributed to the presence of aldehyde and ketone carbonyl groups $(\mathrm{C}=\mathrm{O})$.

Similarly to HA, FAs also showed absorption peaks related to carboxyl and phenolic hydroxyl functional groups. The presence of these functional groups shows their interaction potential with organic and inorganic molecules. Thus, the structural characteristics of FA and HA influence the behavior of several species, including nutrient metal ions (Havelcová et al., 2009), favoring the improvement of the quality of the organic substrates for the production of seedlings. The decrease in the amount of aromatic structures in FA, suggested by the absence of an ABS peak at $270 \mathrm{~nm}$ in the UV-VIS spectrum, is also evidenced by the FTIR spectra of the five FAs, since these did not show a fine absorption and well-defined peak centered at $1510 \mathrm{~cm}^{-1}$. The presence of oxygenated and nitrogenous functional groups, besides the presence of a wide variety of aliphatic and aromatic structures, gives HS a fundamental role in improving the chemical, physical and biological properties of the soilplant system, which are desirable characteristics in the preparation of organic substrates (Passos et al., 2007).

Observing the values of the F-test, the elemental analysis of the substrates indicated that there was no significant difference at 1 and $5 \%$ of probability by the Tukey test in the C, $\mathrm{H}$, $\mathrm{N}$ and $\mathrm{O}$ contents in the five organic substrates (Table 2). In terms of elemental ratios, there were also no significant differences between $\mathrm{H} / \mathrm{C}$ and $\mathrm{O} / \mathrm{C}$ ratios (Table 2). However, a highly significant difference $(F=11.97$ and $p<0.001)$ occurred in the $\mathrm{C} / \mathrm{N}$ elemental ratio between the different organic substrates. 
Table 2. Elementary analysis $\mathrm{CHN} / \mathrm{O}$ and elementary ratios $\mathrm{C} / \mathrm{N}, \mathrm{H} / \mathrm{C}$ and $\mathrm{O} / \mathrm{C}$ of the five organic substrates

\begin{tabular}{cccccccc}
\hline Substrate & $\mathrm{C}$ & $\mathrm{H}$ & $\mathrm{N}$ & $\mathrm{O}$ & $\mathrm{C} / \mathrm{N}$ & $\mathrm{H} / \mathrm{C}$ & $\mathrm{O} / \mathrm{C}$ \\
\hline \multicolumn{7}{c}{$\%$} \\
\hline T1 & $30.77 \mathrm{a}$ & $3.52 \mathrm{a}$ & $2.44 \mathrm{a}$ & $63.27 \mathrm{a}$ & $12.66 \mathrm{~b}$ & $0.11 \mathrm{a}$ & $2.06 \mathrm{a}$ \\
$\mathrm{T} 2$ & $27.27 \mathrm{a}$ & $3.19 \mathrm{a}$ & $2.4 \mathrm{ab}$ & $67.14 \mathrm{a}$ & $11.34 \mathrm{~b}$ & $0.12 \mathrm{a}$ & $2.50 \mathrm{a}$ \\
$\mathrm{T} 3$ & $28.75 \mathrm{a}$ & $3.39 \mathrm{a}$ & $2.46 \mathrm{a}$ & $65.4 \mathrm{a}$ & $11.89 \mathrm{~b}$ & $0.11 \mathrm{a}$ & $2.27 \mathrm{a}$ \\
$\mathrm{T} 4$ & $27.72 \mathrm{a}$ & $3.26 \mathrm{a}$ & $2.54 \mathrm{a}$ & $66.47 \mathrm{a}$ & $11.00 \mathrm{~b}$ & $0.12 \mathrm{a}$ & $2.41 \mathrm{a}$ \\
$\mathrm{T} 5$ & $28.53 \mathrm{a}$ & $3.24 \mathrm{a}$ & $1.79 \mathrm{~b}$ & $66.42 \mathrm{a}$ & $15.88 \mathrm{a}$ & $0.11 \mathrm{a}$ & $2.34 \mathrm{a}$ \\
\hline Mean & 28.61 & 3.32 & 2.33 & 65.74 & 12.56 & 0.12 & 2.32 \\
\hline F-Value & $1.62 \mathrm{~ns}$ & $0.75 \mathrm{~ns}$ & $4.55 \mathrm{~ns}$ & $1.40 \mathrm{~ns}$ & $11.97 * *$ & $1.14 \mathrm{~ns}$ & $1.40 \mathrm{~ns}$ \\
\hline Mean followed by the same letter in the columns do not differ statistically from each other by the Tukey test at the level of 5 and 1\% probability.
\end{tabular}

The lower $\mathrm{N}$ content and, consequently, the higher $\mathrm{C} / \mathrm{N}$ ratio found in the $\mathrm{T} 5$ substrate suggests that in this organic substrate, $\mathrm{N}$ forms are mostly not available, as in lignified tissues or in very poorly decomposed or humid material, such as fibers (Ebeling et al., 2011).

The elemental analysis for the purified humic fractions is presented in Table 3. Both fractions showed low H/C values. One consequence of such a reduction is the decrease in the hydration capacity of HS, which leads to the formation of hydrophobic regions. It has been suggested that hydrophobic moieties of humic substances are significantly related to the stimulation of the proton pump, and the preservation of bioactive molecules such as auxins present in organic matter (Dobbss et al.,
2010), and root increments (Loffredo et al., 2010). High $\mathrm{H} / \mathrm{C}$ values indicate higher alipacity and lower content of aromatic structures in humic substances (Coelho et al., 2013; Goveia et al., 2011; Amir et al., 2010) and consequently, its decrease implies an increase in the degree of humification. Thus, the FA fraction is expected to have higher $\mathrm{H} / \mathrm{C}$ values in relation to $\mathrm{HA}$. This decrease in H/C was observed in all the studied substrates, especially for the T3, T4 and T5 substrates, which characterizes a greater stability and humification of these substrates during the composting process. The lower the atomic ratio $\mathrm{H} / \mathrm{C}$, the higher the resistance of the sample to thermo-degradation, indicating high resistance of aromatic structures to oxidation processes (Cunha et al., 2007).

Table 3. Elementary analysis $\mathrm{CHN} / \mathrm{O}$, elementary ratios $\mathrm{C} / \mathrm{N}, \mathrm{H} / \mathrm{C}$ and $\mathrm{O} / \mathrm{C}$ of humic acids and fulvic acids purified from the five organic substrates

\begin{tabular}{cccccccc}
\hline Substrate & $\mathrm{C}$ & $\mathrm{H}$ & $\mathrm{N}$ & $\mathrm{O}$ & $\mathrm{C} / \mathrm{N}$ & $\mathrm{H} / \mathrm{C}$ & $\mathrm{O} / \mathrm{C}$ \\
\cline { 2 - 8 } & \multicolumn{7}{c}{$\%$ Humic acids } \\
T1 & 51.52 & 4.86 & 3.96 & 39.66 & 13.01 & 0.09 & 0.77 \\
T2 & 51.36 & 5.12 & 4.49 & 39.03 & 11.44 & 0.10 & 0.76 \\
T3 & 50.18 & 5.16 & 5.14 & 39.52 & 9.76 & 0.10 & 0.79 \\
T4 & 50.15 & 5.19 & 6.11 & 38.55 & 8.21 & 0.10 & 0.77 \\
T5 & 51.96 & 5.33 & 3.56 & 39.15 & 14.60 & 0.10 & 0.75 \\
\hline Mean & 51,03 & 5,13 & 4,65 & 39,18 & 11,40 & 0,10 & 0.77 \\
\hline & & & & Fulvic acid & & & \\
T1 & C & $\mathrm{H}$ & $\mathrm{N}$ & $\mathrm{O}$ & $\mathrm{C} / \mathrm{N}$ & $\mathrm{H} / \mathrm{C}$ & $\mathrm{O} / \mathrm{C}$ \\
T2 & 41.14 & 4.55 & 3.94 & 50.37 & 10.44 & 0.11 & 1.22 \\
T3 & 6.19 & 4.44 & 4.02 & 49.41 & 10.48 & 0.11 & 1.17 \\
T4 & 2.14 & 0.82 & 90.85 & 7.55 & 0.35 & 14.68 \\
T5 & 4.35 & 2.37 & 0.60 & 94.17 & 4.77 & 0.83 & 32.93 \\
Mean & 19.33 & 3.31 & 0.61 & 91.73 & 7.13 & 0.76 & 21.09 \\
\hline
\end{tabular}

The HAs showed lower O/C values than the FAs. However, for all substrates, the HA fraction presented values higher than 0.5, suggesting the presence of a greater amount of oxygenated functional groups such as carboxylic and carbohydrates (Fontana et al., 2010). Furthermore, low O/C ratio is another characteristic of the decrease of aliphatic structures and increased humification of SH. For all substrates, the value of the $\mathrm{C} / \mathrm{N}$ ratio was higher 
for the HAs than for the FAs, especially for the T3, $\mathrm{T} 4$, and $\mathrm{T} 5$ substrates. The lower $\mathrm{C} / \mathrm{N}$ ratio for FAs, not due to high $\mathrm{N}$ contents, but due to the low C content, demonstrates the greater oxidation capacity of these structures (Araújo et al., 2011). These substrates also presented the lowest values in the C/N ratio, except the HA for the T5 substrate. The increase in the value of $\mathrm{N}$ may occur as a consequence of the microbial activity and the rapid decomposition of the vegetal tissues that were once part of the organic matter present in the substrates (Campos et al., 2013). The low C/N ratio indicates the incorporation degree of $\mathrm{N}$ into the HS structure and the degree of humification. A high $\mathrm{C} / \mathrm{N}$ ratio indicates low $\mathrm{N}$ incorporation and low humification degree (Cunha et al., 2007).

The values of the $\mathrm{C} / \mathrm{N}$ ratio found in this study were similar to those observed by Baldotto et al. (2013), in which they found average values of 8.3 in deep ocean sediments. However, these values were different from those observed by Campos et al. (2013), where they obtained values ranging from 10.02 to 31.28 for the $\mathrm{C} / \mathrm{N}$

ratio in Yellow Latosol. This behavior explains part of the difficulty of predicting the rate of $\mathrm{N}$ release for plants by the mineralization of organic nitrogen fractions.

Regarding the analysis of the carbon content of the purified humic fractions, the FA fraction presented the lowest $C$ content, implying humic acid/fulvic acid carbon (CHA/CFA) ratio greater than 1.0 (Table 4). This suggests that the humic substances present in the substrates are in more recalcitrant forms such as $\mathrm{AH}$, due to the presence of aromatic functional groups, the higher degree of polymerization and the lower susceptibility to microbial attack. The CHA/ CFA ratio is used as an indicator of the quality of humic substances. This ratio indicates the degree of conversion of the insoluble organic carbon into soluble fractions. Values close to 1 mean a higher equilibrium between the humic fractions and values below 1.0 indicate a higher content of fulvic acids in detriment of the humic acid fraction (Borges et al., 2015).

Table 4. Elementary carbon humic acid/fulvic acid carbon ratio (CAH/CAF) of the five organic substrates

\begin{tabular}{cc}
\hline Substrate & CHA/CFA \\
\hline T1 & 1.25 \\
T2 & 1.22 \\
T3 & 8.11 \\
T4 & 17.53 \\
T5 & 11.94 \\
Mean & 8.01 \\
\hline
\end{tabular}

The substrates showed CHA/CFA ratio values ranging from 1.25 to 17.53, with an average value of 8.01 . Only two substrates, T1 and $\mathrm{T} 2$, presented values close to 1.0, which indicates that the organic substrates, in general, have predominance in the humic acid fraction. The contribution of the $\mathrm{C}$ content in the $\mathrm{AH}$ of the substrates T3, T4, and T5 may favor the better development of the plants. This fraction of $\mathrm{SH}$ has already been widely used in agriculture because it can provide crops with an increase in the size and number of roots, increasing nutrient absorption and growth rates. They also act on the microbiological properties of the plants, increasing the endogenous content of diazotrophic bacteria and, consequently, increasing the beneficial effects on the host plant. Finally, they promote plant growth by the greater rooting and increase in the number of sites of mitosis and emergence of lateral roots (Conceição et al., 2009; Pinheiro et al., 2010).

\section{Conclusions}

In the T1, T2, T3, T4, and T5 substrates the molecular absorption spectroscopic techniques in the ultraviolet-visible region, with bands at 270 and $390 \mathrm{~nm}$ (aromatic), of the humic acids showed humification. Regarding the infrared technique, bands ranging from 3,600 to $3000 \mathrm{~cm}^{-1}$ (carboxylic acids, phenols and alcohols); at 1510 $\mathrm{cm}^{-1}$ (aromatic) and at $1100 \mathrm{~cm}^{-1}$ (complexes with metals) are present for humic acid and fulvic acids fractions, humification, negative charge formation on substrates (CEC) and metal complexation (nutrients and pollutants).

The infrared absorption spectra for 
the fulvic acids in the T3, T4 and T5 substrates showed a decrease in the amount of hydroxyl from alcoholic groups, phenolic and carboxylic groups, showing the lower influence of this fraction on properties such as CEC and metal complexation (nutrients and pollutants).

The T4 substrate shows a higher humification level when compared to T1, T2, T3, and T5 due to the higher carbon-humic acid / fulvic acid-carbon ratio and lower $\mathrm{C} / \mathrm{N}$ ratio, as well as the low $E_{4} / E_{6}$ and $H / C$ ratios.

The higher humification of the T4 substrate associated with the generation of loads and potential of nutrient complexation indicates its greater potential for use in the production of seedlings with the maintenance of the chemical and physical properties of the substrate.

\section{References}

Aeschbacher, M., Sander, M., Schwarzenbach, R.P. 2010. Novel electrochemical approach to assess the redox properties of humic substances. Environmental Science and Technology 44: 8793.

Amir, S., Jouraiphy, A., Meddich, A., Gharous, M. E., Winterton, P., Hafidi, M. 2010. Structural study of humic acids during composting of activated sludge-green waste: Elemental analysis, FTIR and 13C NMR. Journal of Hazardous Materials 177: 524-529.

Araújo, E.A., Ker, J.C., Mendonça, E.S., Silva, I.R., Oliveira, E.K. 2011. Impacto da conversão floresta - pastagem nos estoques e na dinâmica do carbono e substâncias húmicas do solo no bioma Amazônico. Acta Amazonica 41: 103-114.

Baldotto, M.A., Canellas, L.P., Rosa, R.C.C., Rangel, T.P., Salomão, M.S.M.B., Rezende, C.E. 2011 . Capacidade de oxidação como índice de estabilidade da matéria orgânica de sedimentos de acordo com gradiente fuvial-estaurino do Rio Paraíba do Sul. Química Nova 34: 973-978.

Baldotto, M.A, Gobo, A.A.R., Salomão, M.S.M.B., Rezende, C.E., Camargo, P.B. 2013. Frações da matéria orgânica e propriedades redox de substâncias húmicas em sedimentos de oceanos profundos. Química Nova 36: 1288-1295.

Borges, C.S., Ribeiro, B.T., Wendling, B., Cabral, D.A. 2015. Agregação do solo, carbono orgânico e emissão de $\mathrm{CO}_{2}$ em áreas sob diferentes usos no Cerrado, região do Triângulo Mineiro. Revista Ambiente e Água 10: 660-675.

Campos, L.P., Leite, L.F.C., Maciel, G.A., Brasil, E.L., Iwata, B.F. 2013. Estoques e frações de carbono orgânico em Latossolo Amarelo submetido a diferentes sistemas de manejo. Pesquisa Agropecuária Brasileira 48: 304-312.

Canellas, L.P., Teixeira Junior, L.R.L., Dobbss, L.B., Silva, C.A., Medici, L.O., Zandonadi, D.B., Façanha, A.R. 2008. Humic acids crossinteractions with root and organic acids. Annals of Applied Biology 153: 157-166.

Coelho, M.S., Mendonça, E.S., Lima, P.C., Guimarães, G.P., Cardoso, I.M. 2013. Qualidade da matéria orgânica de solos sob cultivo de café consórciado com adubos verdes. Revista Brasileira de Ciência do Solo 37: 1576-1586.

Conceição, P.M., Vieira, H.D., Canellas, L.P., Olivares, F.L., Conceição, P.S. 2009. Efeito dos ácidos húmicos na inoculação de bactérias diazotróficas endofíticas em sementes de milho. Ciência Rural 39: 1880-1883.

Cunha, T.J.F., Madari, B.E., Benites, V.M., Canellas, L.P., Novotny, E.H., Moutta, R.O., Trompowsky, P.M., Santos, G.A. 2007. Fracionamento químico da matéria orgânica e características de ácidos húmicos de solos com horizonte a antrópico da Amazônia (Terra Preta). Acta Amazazonica 37: 91-98.

David, J., Šmejkalová, D., Hudecová, Š,. Zmeškal, O., Wandruszka, R.V., Gregor, T., Kučerík, J. 2014. The physico-chemical properties and biostimulative activities of humic substances regenerated from lignite. Springer Plus 3: 156-171.

Dobbss, L.B., Rumjaneck, V.M., Baldotto, M.A., Velloso, A.C.X., Canellas, L.P. 2009. Caracterização química e espectroscópica de ácidos húmicos e fúlvicos isolados da camada superficial de latossolos brasileiros. Revista Brasileira de Ciência do Solo 33: 51-63.

Dobbss, L.B., Canellas, L.P., Olivares, F.L., Aguiar, N.O., Peres, L.E.P., Azevedo, M., Spaccini, R., Piccolo, A., Façanha, A.R. 2010. Bioactivity of Chemically Transformed Humic Matter from Vermicompost on Plant Root Growth. Journal of Agricultural and Food Chemistry 58: 3681-3688.

Ebeling, A. G., Anjos, L.H.C., Perez, D.V., Pereira, M.G., Gomes, F.W.F. 2011. Atributos químicos, carbono orgânico e substâncias húmicas em organossolos háplicos de várias regiões do Brasil. Revista Brasileira de Ciência do Solo 35: 325-336.

Embrapa. Empresa Brasileira de Pesquisa Agropecuária. Manual de Métodos de Análise de Solo. $2^{a}$ ed. Embrapa Solos, Rio de Janeiro, $2011.225 \mathrm{p}$.

Fernandes, A.N., Giovanela, M., Esteves, V.I., Sierra, M.M.S. 2010. Elemental and spectral properties of peat and soil samples and their respective humic substances. Journal of 
Molecular Structure 971: 33-38.

Fialho, L.L., Silva, W.T.L., Milori, D.M.B.P., Simões, M.L., Martin-Neto, L., Saab, S.C. 2010. Interferência da lignina na quantificação de radicais livres no processo de compostagem. Química Nova 33: 346-369.

Fontana, A., Brito, R.J., Pereira, M.G., Loss, A., Benites, V.M. 2010. Caracterização de substâncias húmicas da camada superficial do solo sob coberturas vegetais. Magistra 22:49-56.

Goveia, D., Rocha, J.C., Oliveira, L.C., Morais, L.C., Campos, V., Fraceto, L.F., Rosa, A.H. 2011. Caracterização estrutural das substâncias húmicas aquáticas extraídas dos rios Itapanhaú e Ribeira de Iguape. Química Nova 34: 753-758.

Graber, E.R., Tsechansky, L., Mayzlish-Gati, E., Shema, R., Koltai, H. 2015. A humic substances product extracted from biochar reduces Arabidopsis root hair density and length under P-sufficient and P-starvation conditions. Plant and Soil 395: 21-30.

Havelcová, M., Mizera, J., Sýkorová, I., Pekařc, M. 2009. Sorption of metal ions on lignite and the derived humic substances. Journal of Hazardous Materials 161: 559-564.

Loffredo, E., Palazzo, A.J., Senesi, N., Clapp, C.E., Bashore, T.L. 2010. Germination and early growth of slickspot peppergrass (Lepidium papilliferum) as affected by desert soil humic acids. Soil Science 175: 186-193.

Matilainen, A., Gjessing, E., Lahtinen, T., Hed, L., Bhatnagar, A., Sillanpää, M. 2011. An overview of the methods used in the characterization of natural organic matter (NOM) in relation to drinking water treatment. Chemosphere 83: 1431-1442.

McCarthy, P.E., RICE, J.A. 1985. Spectroscopic methods (other than NMR) for determining functionality in humic substances. In: Aiken, G.R., McKnight, D.M., Wershaw, R.L., MacCarthy, P. (ed). Humic substances in soil, sediment and water: geochemistry, isolation and characterization. John Wiley, New York, USA. p.527-559.

Miranda, C.C., Canellas, L.P., Nascimento, M.T. 2007. Caracterização da matéria orgânica do solo em fragmentos de mata atlântica e em plantios abandonados de eucalipto. Revista Brasileira de Ciência do Solo 31: 905-916.

Passos, R.R., Ruiz, H.A., Mendonça, E.S., Cantarutti, R.B., Souza, A.P. 2007. Substâncias húmicas, atividade microbiana e carbono orgânico lábil em agregados de um latossolo vermelho distrófico sob duas coberturas vegetais. Revista Brasileira de Ciência do Solo 31: 1119-1129.
Pernet-Coudrier, B., Varrault, G., Saad, M., Crové, J.P., Dignac, M.F., Mouchel, J.M. 2011. Characteristics of dissolved organic matter in Parisian urban aquatic systems: predominance of hydrophilic and proteinaceous structures. Biogeochemistry 106: 89-106.

Pessoa, P.M.A., Duba, G.P, Barros, R.B., Freire, M.B.G.S., Nascimento, C.W.A., Correa, M.M. 2012. Frações de carbono orgânico de um latossolo húmico sob diferentes usos no agreste brasileiro. Revista Brasileira de Ciência do Solo 36:97-104.

Pinheiro, G.L., Silva, C.A., Furtini Neto, A.E. 2010. Crescimento e nutrição de clone de eucalipto em resposta à aplicação de concentrações de C-ácido húmico. Revista Brasileira de Ciência do Solo 34: 1217-1229.

Primo, D.C., Menezes, R.S.C., Silva, T.O. 2011. Substâncias húmicas da matéria orgânica do solo: uma revisão de técnicas analíticas e estudos no nordeste brasileiro. Scientia Plena 7: 1-13.

Rodríguez, F.J., Núñez, L.A. 2011 . Characterization of aquatic humic substances. Water and Environment Journal 25: 163-170.

Rodríguez, F.J, Schlenger, P., García-Valverde, M.A. 2014. Comprehensive structural evaluation of humic substances using several fluorescence techniques before and after ozonation. Part I: Structural characterization of humic substances. Science of the Total Environment 476-477: 718730.

Rodríguez, F.J., Schlenger, P., García-Valverde, M. 2016. Monitoring changes in the structure and properties of humic substances following ozonation using UV-Vis, FTIR and ' $\mathrm{H}$ NMR techniques. Science of the Total Environment 541: 623-637.

Silva, A.C., Silva, V.E., Silva, B.P., Camargo, P.B., Pereira, R.C., Barra, U.M., Botelho, A.M.M., Torrado, P.V. 2013. Composição lignocelulósica e isótopica da vegetação e da matéria orgânica do solo de uma turfeira tropical. II - substâncias húmicas e processos de humificação. Revista Brasileira de Ciência do Solo 37: 134:144.

Silva, F.A.S., Azevedo C.A.V. 2016. The Assistat Software Version 7.7 and its use in the analysis of experimental data. African Journal of Agricultural Reserach 11: 3733-3740.

Smith, M., Ha, S., Amonette, J.E., Dallmeyer, I., Garcia-Perez, M. 2015. Enhancing cation exchange capacity of chars through ozonation. Biomass and Bioenergy 81: 304-314.

Stevenson, F.J. 1994. Humus chemisthy, genesis, composition, reactions. 2nd ed. John Wiley, New York, USA. 512p. 
Swift, R.S. 1996. Organic matter characterization. In: Sparks, D.L., Page, A.I., Helmke, P.A., Loeppert, R.H., Soltanpour, P.N., Tabatabai, M.A., Johnston, C.T., Summer, M.E. (ed). Methods of soil analysis: Chemical methods. Soil Science Society of America, Madison, USA. p.1018-1020.

Thorn, K.A., Cox, L.G. 2009. N-15 NMR spectra of naturally abundant nitrogen in soil and aquatic natural organic matter samples of the International Humic Substances Society. Organic Geochemistry 40: 484-499.

Trevisan, S., Franciosco, O., Quaggiotti, S., Nardi, S. 2010. Humic substances biological activity at the plant-soil interface. Plant Signaling and Behavior 5: 635-643.

Valencia, S., Marín, J.M., Restrepo, G., Frimmel, F.H. 2013. Application of excitation-emission fluorescence matrices and UV/Vis absorption to monitoring the photocatalytic degradation of commercial humic acid. Science of the Total Environment 442: 207-214.

Wang, A., Song, X.Y.,Wang, N., Li, C.X., Wang, W., Zhang, J.J. 2014. Characteristics of Soil Humic Substances as Determined by Conventional and Synchrotron Fourier Transform Infrared Spectroscopy. Journal of Applied Spectroscopy 81: 843-849.

Zalba, P. Amiotti, N.M., Galantini, J.A., Pistola, S. 2016. Soil Humic and Fulvic Acids from Different Land-Use Systems Evaluated $B y E_{4} / E_{6}$ Ratios. Communications in Soil Science and Plant Analysis 47: 1675-1679.

Zhou, Y., Selvam, A., Wong, J.W.C. 2014. Evaluation of humic substances during co-composting of food waste, sawdust and Chinese medicinal herbal residues. Bioresource Technology 168: 229234. 